\title{
PENGARUH LIKUIDITAS DAN LEVERAGE TERHADAP PENGUNGKAPAN CORPORATE SOCIAL RESPONSIBILITY PADA PERUSAHAAN MANUFAKTUR YANG TERDAFTAR DI BURSA EFEK INDONESIA (BEI) PERIODE 2015-2019
}

\author{
Safrin Maruli Tua \\ Fakultas Ekonomi Universitas Krisnadwipayana \\ Jalan Unkris Jatiwaringin Jakarta Timur \\ $\underline{\text { Safmata@gmail.com }}$
}

\begin{abstract}
The Effect of Liquidity and Leverage on Disclosure of Corporate Social Responsibility in Manufacturing Companies Listed on the Indonesia Stock Exchange (IDX) 2015-2019 period. The purpose of this study is to determine whether the effect of liquidity on disclosure of corporate social responsibility in manufacturing companies listed on the Indonesia Stock Exchange (IDX) for the 2015-2019 period, to determine whether the effect of leverage on disclosure of corporate social responsibility in manufacturing companies listed on the Indonesia Stock Exchange (IDX) for the 2015-2019 period, to determine whether the effect of liquidity and leverage on the disclosure of corporate social responsibility in manufacturing companies listed on the Indonesia Stock Exchange (IDX) for the 2015-2019 period. This type of research is a type of quantitative research. The type of data used in this study is secondary data in the form of corporate financial reports listed on the Indonesia Stock Exchange, such as corporate financial reports and corporate social responsibility. The population in this study were all manufacturing companies listed on company reports on the IDX in 2015,2015,2017,2018 and 2019. The sample in this study was conducted using purposive sampling method, the total sample in this study was 50 data from 10 manufacturing companies listed on the Indonesia Stock Exchange. The data analysis method used multiple linear regression. Liquidity has a positive and significant effect on the disclosure of corporate social responsibility in manufacturing companies listed on the IDX for the 2015-2019 period. This is indicated by a significance level of 0.026 with a regression coefficient of 0.037 . leverage has a negatife and significant effect on the disclosure of corporate social responsibility in manufacturing companies listed on the IDX for the 2015-2019 period. Tihis is indicated by a significance level of 0.005 with a regression coefficient of -0.047 .
\end{abstract}

Keyword : Liquidity, Leverage and Corporate Social Responsibility

PENDAHULUAN

Perkembangan dunia usaha yang pesat mengakibatkan banyak perusahaan besar yang berkembang saat ini, hal ini bertujuan searah dengan pertanggungjawaban sosial yang harus dilakukan oleh perusahaan.
Pertanggungjawaban sosial perusahaan atau corporate social responsibility (CSR) bertujuan untuk meningkatkan nilai perusahaan dengan mempertanggungjawabkan lingkungan fisik dan lingkungan sosialnya. Dalam Adeneye dan 
Ahmad (2015) menjelaskan bahwa corporate social responsibility memberikan pemahaman bahwa perusahaan memiliki kemampuan dan rasa tanggung jawab terhadap pertumbuhan dan perkembangan lingkungan sekitar perusahaan tersebut beroperasi.

Pengungkapan corporate social responsibility memang tidak memberikan profit kepada perusahaan dalam jangka pendek tetapi CSR memberikan keuntungan dimasa datang, oleh karena itu hasil akhir dari strategi CSR akan menjadi investasi penting bagi perusahaan. Corporate Social Responsibility mampu meningkatkan citra perusahaan dengan melakukan Corporate Social Responsibility, konsumen dapat lebih mengenal perusahaan sebagai perusahaan yang selalu melakukan kegiatan yang baik bagi masyarakat. CSR mampu memperkuat "Brand" perusahan melalui kegiatan memberikan product knowledge kepada konsumen dengan cara membagikan produk secara gratis, dapat menimbulkan kesadaran konsumen akan keberadaan produk perusahaan sehingga dapat meningkatkan posisi brand perusahaan.CSR mampu mengembangkan kerjasama dengan para pemangku kepentingan, CSR mampu membedakan perusahaan dengan pesaingnya perusahaan mempunyai kesempatan menonjolkan keunggulan komparatifnya sehingga dapat membedakannya dengan pesaing yang menawarkan produk atau jasa yang sama. CSR pun mampu menghasilkan inovasi dan pembelajaran untuk meningkatkan pengaruh perusahaan merencanakan CSR secara konsisten dan berkala dapat memicu inovasi dalam perusahaan yang pada akhirnya dapat meningkatkan peran dan posisi perusahaan dalam bisnis global. Alat ukur Corporate Social Responsibility diproksikan ke dalam pengungkapan Corporate Social Responsibility, dimana penelitian menggunakan checklist yang mengacu berdasarkan Global Reporting Initiative (GRI) G.4 didalamnya terdiri dari kategori ekonomi (9 indikator), lingkungan (34 indikator), praktek ketenagakerjaan dan kenyamanan kerja (16 indikator), hak asasi manusia (12 indikator), masyarakat (11 indikator), dan tanggung jawab atas produk (9 indikator). Dalam penelitian ini pengungkapan corporate social responsibility diukur menggunakan indikator Global Resporting Initiative (GRI). GRI mampu mengukur kinerja organisasi sehubungan dengan undang-undang, norma, kode, standar kinerja dan inisiatif suka rela, menunjukkan komitmen organisasi terhadap pembangunan berkelanjutan,dan bandingkan kinerja organisasi dari waktu ke waktu. Ada beberapa faktor yang mempengaruhi pengungkapan 
corporate social responsibility suatu perusahaan diantaranya likuiditas dan leverage.

Salah satu cara agar kelangsungan hidup perusahaan dapat dipertahankan adalah dengan melakukan pemantauan tingkat likuiditasnya. Sebagai perusahaan yang berorientasi pada laba, maka laba mempunyai peranan yang sangat dominan dalam perusahaan untuk menentukan apakah perusahaan tersebut akan pailit atau dapat terus bertahan di suatu industri. Menurut Agus (2010) Likuiditas merupakan kemampuan perusahaan untuk memenuhi kewajiban finansial yang berjangka pendek tepat pada waktunya. Likuiditas dapat diartikan sebagai kemampuan suatu perusahaan memenuhi kewajiban - kewajiban keuangannya dalam jangka pendek atau yang harus segera dibayar, Munawir (2007). Perusahaan yang mempunyai cukup kemampuan untuk membayar hutang jangka pendek disebut perusahaan yang likuid, sedangkan perusahaan yang tidak mempunyai kemampuan untuk membayar hutang jangka pendek yang cukup, disebut ilikuid. Kesehatan suatu perusahaan tercermin dari tingginya rasio likuiditas, menurut Wiratna Sujarweni (2017) likuiditas dapat diukur dengan Current Ratio, Quick Ratio, dan Cash Ratio. Dalam penelitian ini likuiditas diukur menggunakan current ratio (CR) yang merupakan perbandingan antara aktiva lancar (current asset) dengan hutanglancar (current liabilities). Current Ratio yang tinggi menunjukkan kekuatan perusahaan dari segi kemampuan untuk memenuhi hutang lancar dari harta lancar yang dimiliki sehingga hal ini dapat meningkatkan pengungkapan corporate social responsibility perusahaan dan meningkatkan kepercayaan pihak luar terhadap perusahaan tersebut.

Perusahaan juga dihadapkan pada masalah sumber dana. Dana selalu dibutuhkan untuk menutupi seluruh atau sebagian dari biaya yang diperlukan perusahaan, baik jangka pendek maupun jangka panjang. Sumber-sumber dana secara garis besar dapat diperoleh dari modal sendiri dan pinjaman. Perusahaan dapat memilih dana dari salah satu sumber tersebut atau kombinasi dari keduanya. Kombinasi dari penggunaan dana dikenal dengan nama rasio penggunaan dana pinjaman atau hutang atau dikenal dengan nama rasio leverage. Menurut Kasmir dalam Purnamasari (2017) Leverage adalah kemampuan perusahaan untuk memenuhi perusahaan untuk memenuhi kewajiban atau utang jangka panjangnya . Kasmir (2018) menunjukkan bahwa pratiknya, apabila dari hasil perhitungan, perusahaan ternyata memiliki rasio leverage yang tinggi, hal ini akan berdampak timbulnya risiko 
gagal bayar kewajiban utang yang dihadapi perusahaan, tetapi juga memberikan dampak positif bagi kelangsungan operasional bisnis perusahaan, Sebaliknya, apabila perusahaan memiliki rasio leverage lebih rendah tentu mempunyai risiko kerugian lebih kecil pula terutama pada saat perekonomian menurun. Dampak ini juga mengakibatkan rendahnya tingkat hasil pengembalian (return) pada saat perekonomian tinggi. Oleh karena itu, manajer keuangan dituntut untuk mengelola rasio ini dengan baik sehingga mampu menyeimbangkan pengembalian yang tinggi dengan tingkat risiko yang dihadapi. Perusahaan dengan rasio leverage yang lebih tinggi biasanya berusaha menyampaikan lebih banyak informasi yang lebih detail dalam laporan tahunan untuk memenuhi kebutuhan tersebut dibandingkan dengan perusahaan yang tinggi leverage yang lebih rendah (Putri, 2017). Dan apabila perusahaan menggunakan lebih banyak hutang dibandingkan dengan modal sendiri maka tingkat leverage akan menurun, hal tersebut terjadi karena beban bunga yang ditanggung perusahaan juga meningkat. Hal ini akan berdampak terhadap perusahaan tersebut. Menurut Kasmir (2016) leverage dapat diukur dengan Debt to Asset Ratio, Debt to Equity Ratio, Long Term Debt to Equity Ratio, Times Interest Earned Ratio, dan Fixed
Charge Coverage. Dalam penelitian ini leverage diukur menggunakan Debt to Equity Ratio (DER), yaitu rasio yang digunakan untuk mengetahui perbandingan antara total utang dengan modal sendiri. Artinya dapat digunakan untuk mengetahui seberapa besar modal yang dijadikan sebagai jaminan atas hutang perusahaan. Bagi pihak kerditor, jika nilai dari rasio ini besar atau tinggi akan semakin tidak menguntungkan. Hal tersebut dikarenakan akan semakin tinggi resiko yang ditanggung oleh pihak kreditur atas kegagalan yang mungkin akan terjadi di perusahaan. Namun apabila nilai rasio ini rendah, maka akan semakin tinggi jumlah pendanaan yang disediakan oleh pemilik perusahaan.

Dalam penelitian ini perusahaan manufaktur dijadikan sebagai objek penelitian. Perusahaan manufaktur merupakan jenis usaha yang berkembang pesat dan memiliki ruang lingkup yang sangat besar dalam melakukan proses produksi yang tidak terputus, Ambarwati, Yuniarta, \& Sinarwati (2015). Perusahaan manufaktur dipilih karena memiliki potensi dalam mengembangkan produknya lebih cepat dengan melakukan inovasiinovasi yang cenderung mempunyai pangsa pasar yang lebih luas dibandingkan perusahaan lainnya. Disamping itu juga karena saham dalam 
perusahaan manufaktur lebih banyak menarik minat para investor daripada perusahaan lainnya. Berikut ini akan disajikan data rata-rata pengungkapan corporate social responsibility perusahaan manufaktur yang terdaftar di Bursa Efek Indonesia (BEI) periode 2015-2019.

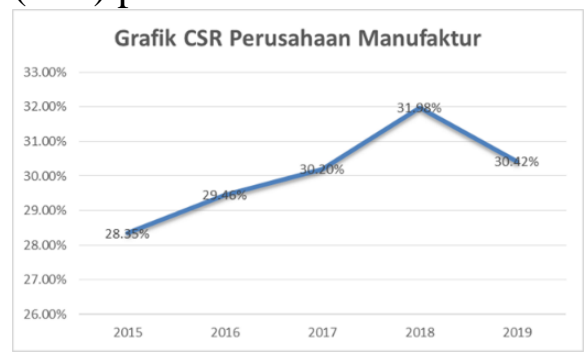

Gambar1.Rata-rata Pengungkapan Corporate Social Responsibility Perusahaan Manufaktur Yang terdaftar di Bursa Efek Indonesia periode 2015-2019

Sumber : idx.co.id diolah oleh penulis, 2021

Dari gambar 1 diatas menjelaskan rata-rata Corporate Social Responsibility (CSR) perusahaan manufaktur periode 2015 sampai dengan 2019 terjadi fluktuasi, dimana tahun 2015 Corporate Social Responsibility sebesar $28,35 \%$, pada tahun 2016 CSR mengalami peningkatan menjadi $29,46 \%$, pada tahun 2017 CSR mengalami peningkatan menjadi $30,20 \%$, sedangkan pada tahun 2018 CSR mengalami peningkatan menjadi $31,98 \%$, dan pada tahun 2019 CSR menurun menjadi $30,42 \%$.

\section{Corporate}

Social Responsibility tidak meningkat secara konsisten setiap tahunnya. Menurunnya CSR dapat disebabkan oleh kondisi perekonomi nasional yang sedang berkejolak..CSR meningkat dapat diartikan bahwa dengan sumber daya yang dimiliki perusahaan mampu memaksimalkan nya. Hal ini berarti, dengan adanya yang dimiliki perusahaan mampun memanfaatkan sumberdaya dengan baik, sehingga dapat menghasilkan keuntungan bagi perusahaan.

Berdasarkan penelitian terdahulu, terdapat beberapa perbedaan hasil menurut Putri (2017) menunjukan bahwa likuiditas berpengaruh positif dan signifikan terhadap pengungkapan CSR. Sedangkan hasil penelitian Hari (2011) mengatakan bahwa likuiditas tidak berpengaruh terhadap pengungkapan CSR. Ikhsan (2014) bahwa likuiditas berpengaruh terhadap pengungkapa CSR. Arita dan Mukthar (2019) menunjukan bahwa likuiditas tidak berpengaruh signifikan terhadap pengungkapan CSR. Pengaruh leverage terhadap pengungkapan corporate social responsibility juga memiliki hasil yang berbeda pada penelitian terdahulu, menurut Putri (2017) menunjukkan bahwa leverage berpengaruh positif dan signifikan terhadap pengungkapan CSR. Menurut Lidya (2011) dan Munif (2011) mengatakan bahwa variable leverage berpengaruh negatif terhadap pengungkapan CSR. Sedangkan hasil penelitian Santioso dan Chandra (2012) 
menunjukkan bahwa leverage tidak memiliki pengaruh signifikan terhadap CSR.

Berdasarkan

hasil

penelitian terdahulu dapat dilihat variabel-variabel yang digunakan memiliki arah pengaruh dan signifikan yang berbeda-beda terhadap pengungkapan corporate social responsibility perusahaan. Untuk itu peneliti tertarik untuk meneliti dengan rumusan masalah

1. Untuk mengetahui pengaruh likuiditas terhadap pengungkapan corporate social responsibility pada perusahaan manufaktur yang terdaftar di Bursa Efek Indonesia (BEI) periode 20151019.

2. Untuk mengetahui pengaruh leverage terhadap pengungkapan corporate social responsibility pada perusahaan manufaktur yang terdaftar di Bursa Efek Indonesia (BEI) periode 20152019.

3. Untuk pengaruh likuiditas dan leverage terhadap pengungkapan corporate social responsibility yang terdaftar di Bursa Efek Indonesia (BEI) periode 20152019.

\section{LANDASAN TEORI}

\section{Corporate Social Responsibility}

Pengertian corporate social responsibility menurut ISO
26000 dalam Rusdianto (2013: 7) adalah sebagai berikut:

"Tanggung jawab suatu organisasi atas dampak dari keputusan dan aktivitasnya terhadap masyarakat dan lingkungan, melalui perilaku yang transparan dan etis, yang: konsisten dengan pembangunan berkelanjutan dan kesejahteraan masyarakat; memperhatikan kepentingan dari para stakeholder, sesuai hukum yang berlaku dan konsisten dengan normanorma internasional; terintegrasi di seluruh aktivitas organisasi, dalam pengertian ini meliputi baik kegiatan, produk maupun jasa."

Sedangkan
Unenurut
Pndang-Undang
Terbatas No. 40 Tahun 2007 pasal
satu butir tiga adalah sebagai
berikut:
"Tanggung Jawab Sosial dan
Lingkungan adalah komitmen
Perseroan untuk berperan serta
dalam pembangunan ekonomi
berkelanjutan guna meningkatkan
kualitas kehidupan dan
lingkungan yang bermanfaat, baik
bagi Perseroan sendiri, komunitas
setempat, maupun masyarakat
pada umumnya."

\section{Prinsip-prinsip Corporate Social Responsibility}

Crowther David dalam Nor Hadi (2014:59) mengurai prinsip-prinsip tanggung jawab sosial (social responsibility) menjadi tiga, yaitu:

1. Sustainability. 
2. Accountability.

3. Transparancy.

\section{Pengungkapan Social Responsibility \\ Corporate}

Menurut Hery (2012: 143) pengungkapan corporate social responsibility adalah sebagai berikut:

"Pengungkapan CSR yang sering juga disebut sebagai social disclosure, corporate social reporting, atau social accounting merupakan proses 37 pengkomunikasian dampak sosial dan lingkungan dari kegiatan ekonomi organisasi terhadap kelompok khusus yang berkepentingan dan terhadap masyarakat secara keseluruhan".

(2012) mendefinisikan pengungkapan corporate social responsibility adalah sebagai berikut:

"Pengungkapan sosial sebagai suatu pelaporan atau penyampaian informasi kepada stakeholders mengenai segala aktivitas perusahaan yang berhubungan dengan lingkungan sosialnya".

Faktor-faktor pengungkapan Corporate Responsibility

Menurut Deegan dalam Rusdianto (2013) menjelaskan ada banyak hal yang membuat perusahaan mengungkapkan CSRnya, yaitu:

1. Keinginan untuk mematuhi persyaratan yang terdapat di dalam Undang-Undang.
2. Pertimbangan rasionalitas ekonomi (Economic Ratiobality).

3. Keinginan dalam akuntanbilitas atau pertanggungjawaban untuk melaporkan.

4. Keinginan untuk mematuhi persyaratan peminjaman.

5. Untuk memenuhi atau menyesuaikan dengan harapan/keinginan masyarakat.

6. Sebagai konsekuensi dari ancaman terhadap legitimasi masyarakat.

7. Untuk me-manage kelompok stakeholder tertentu yang dimiliki pengaruh besar terhadap perusahaan.

8. Untuk menarik investor.

9. Untuk memenuhi persyaratan industri (code of product) tertentu.

10. Untuk memenangkan penghargaan pelaporan tertentu.

\section{Likuiditas}

Menurut Hery (2015) Rasio Likuiditas adalahrasio yang menunjukkan kemampuan perusahaan dalam memenuhi kewajiban atau membayar utang jangka pendeknya. Likuiditas adalah masalah yang berhubungan dengan masalah kemampuan suatu perusahaan untuk memenuhi kewajiban finansialnya yang segera harus dipenuhiRiyanto (2008) 


\section{Leverage}

Menurut Supacua (2015) Leverage adalah alat untuk mengukur seberapa besar perusahaan tergantung pada kreditur dalam membiayai asset perusahaan. Perusahaan yang memiliki tingkat leverage tinggi berarti sangat bergantung pada pinjaman luar untuk membiayai asetnya. Sedangkan perusahaan memiliki tingkat leverage rendah. Lebih banyak membiayai asetnya dengan modal sendiri. Leverage adalah merupakan rasio yang digunakan untuk mengukur sejauh mana aset perusahaan dibiayai dengan utang, artinya berapa besar jumlah utang yang digunakan perusahaan untuk membiayai kegiatan usahanya jika dibadingkan dengan menggunakan modal sendiri agar perbandingan kedua rasio ini dapat terlihat jelas, kita dapat menggunakan rasio leverage Kasmir (2016).

\section{METODE PENELITIAN}

\section{Waktu dan Lokasi Penelitian}

Sesuai dengan permasalahan yang akan diteliti, penelitian ini dilakukan pada Perusahaan Manufaktur yang terdaftar di Bursa Efek Indonesia ( BEI) periode 2015-2019. Bursa Efek Indonesia (BEI) dipilih sebagai tempat penelitian karena merupakan Bursa Efek yang memiliki catatan history yang panjang dan lengkap mengenai perusahaan go public. Penlitian dilakukan pada bulan Juni 2020November 2020.

\section{Desain Penelitian}

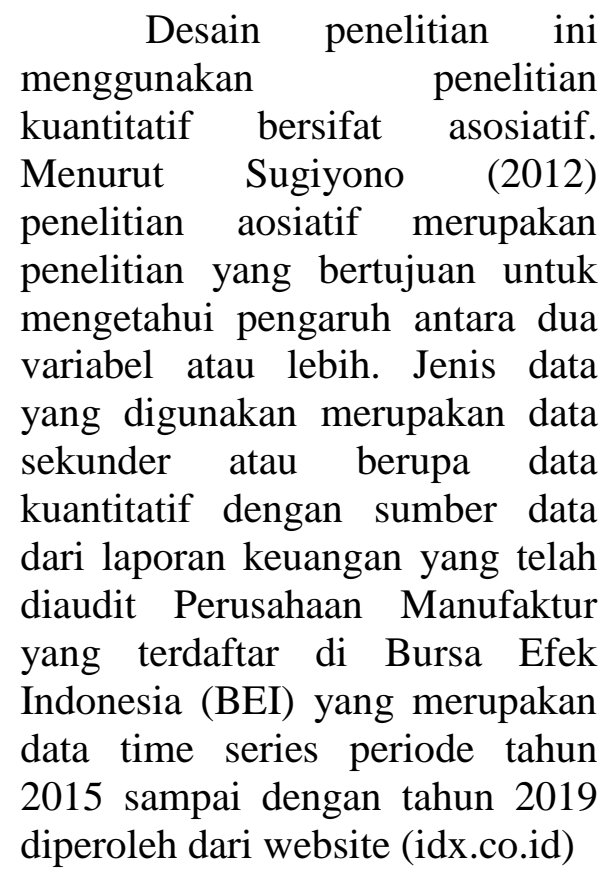

\section{Populasi dan Sampel}

Populasi dalam penelitian ini adalah semua perusahaan manufaktur yang terdaftar di laporan perusahaan di BEI tahun 2015, 2016, 2017, 2018 dan 2019. Jadi dalam penelitian ini sampel yang digunakan untuk penelitian ini adalah laporan keuangan perusahaan di BEI. 


\section{HASIL PENELITIAN DAN PEMBAHASAN}

\section{Hasil analisis uji statistik deskriptif}

Tabel1. Statistic deskriptif

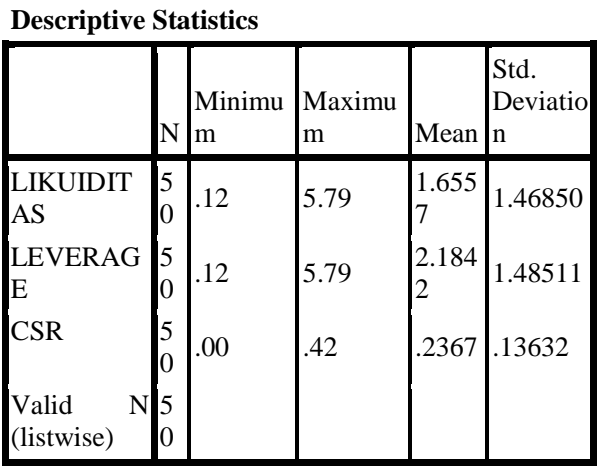

Berdasarkan tabel 1. di atas menunjukkan pengukuran dari variabel dari $\mathrm{N}$ sebanyak 50 dalam kurun waktu 2015-2019 mengenai statistik deskriptif dengan pengunakan SPSS, maka dapat dijelaskan sebagai berikut :

1. Variabel ini menghasilkan nilai minimum 0,12 , nilai maksimum sebesar 5,79, ratarata (mean) 1,6557, dengan nilai standar deviasi sebesar 1,46850 dan dengan jumlah pengamatan sebanyak 50 sampel Nilai rata-rata lebih besar dari standar devisiasi yaitu $1,6557>1,46850$, menunjukkan bahwa sebaran variabel data yang kecil atau tidak adanya kesenjangan yang cukup besar dari data Likuiditas terendah dan tertinggi. Likuiditas tertinggi terjadi pada PT Betonjaya manunggal, Tbk. pada tahun 2018 yaitu sebesar 5,79 sedangkan Likuiditas terendah terjadi pada PT Budi Acid Jaya, Tbk. pada tahun 2019 sebesar 0,12.

2. Variabel ini menghasilkan nilai minimum 0,12 , nilai maksimum 5,79, rata-rata (mean) 2,1842, dengan nilai standar deviasi 1,48511 dan dengan jumlah pengamatan sebanyak 50 sampel. Nilai rata-rata lebih besar dari standar devisiasi yaitu 2,1842>1,48511, menunjukan bahwa sebaran variabel data yang kecil atau tidak adanya kesenjangan yang cukuo besar dari data Leverage terendah dan tertinggi. Leverage tertinggi terjadi pada PT Betonjaya Manunggal, Tbk. pada tahun 2018 yaitu sebesar 5,79 sedangkan Leverage terendah terjadi pada PT Budi Acid Jaya, Tbk. pada tahun 2019 sebesar 0,12.

3. Variabel ini menghasilkan nilai minimum 0,00 , nilai maksimum 0,42 , rata-rata (mean) 0,2367, dengan nilai standar deviasi 0,13632 dan dengan jumlah pengamatan sebanyak 50 sampel. Nilai rata-rata lebih besar dari standar deviasi yaitu 0,2367> 0,13632, menunjukan bahwa sebaran variabel data yang kecil atau tidak adanya kesenjangan yang cukup besar 
dari data Corporate Social Responsibility terendah dan tertinggi. Corporate Social Responsibility tertinggi terjadi pada PT Asai Plast Indrustries, Tbk. pada tahun 2019 sebesar 0,42 sedangkan Corporate

Social

Responsibility terendah terjadi pada PT Wilmar Cahaya Indonesia, Tbk. pada tahun 2016 sebesar 0,00 .

\section{Uji asumsi klasik}

\section{Uji Normalitas}

Tabel2. Uni normalitas

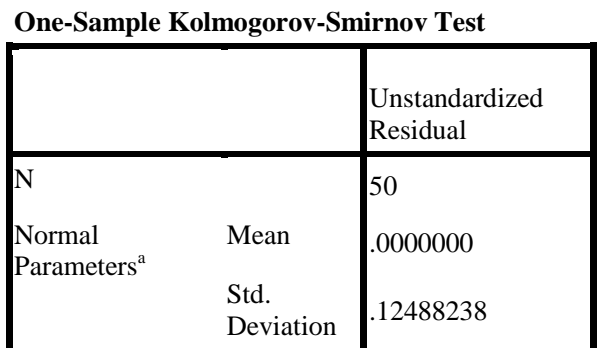

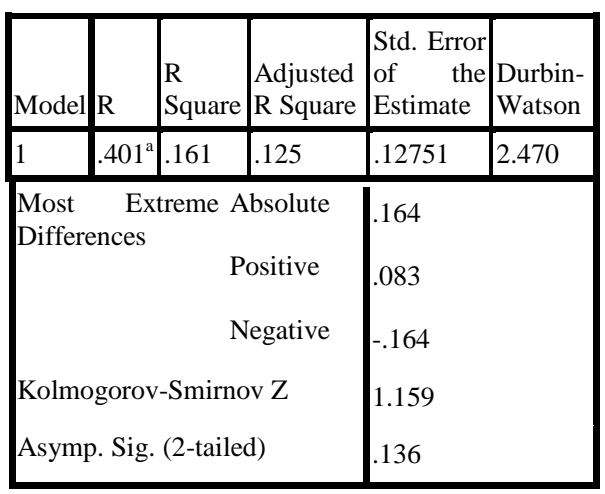

Berdasarkan hasil oleh data uji normalitas bahwa Pengaruh likuiditas dan leverage terhadap pengungkapan corporate social responsibility nilai signifikansi yang diperoleh sebesar $0.136>0,05$ dapat dikatakan terdistribusi secara normal.

\section{Uji multikolineritas}

Tabel 3 uji multikolinearitas

\begin{tabular}{|l|l|l|}
\hline \multirow{2}{*}{ Model } & \multicolumn{2}{|l|}{ Collinearity Statistics } \\
\cline { 2 - 3 } & Tolerance & VIF \\
\hline (Constant) & & \\
\hline LIKUIDITAS & .601 & 1.665 \\
\hline LEVERAGE & .601 & 1.665 \\
\hline
\end{tabular}

Berdasarkan hasil olah data uji multikolinearitas diatas diketahui nilai tolerance untuk variabel likuiditas sebesar 0,601 > 0,10 dan nilai VIF sebesar 1,665 < 10 sehingga variabel likuiditas dinyatakan tidak terjadi gejala multikolinieritas. Sedangakan nilai tolerance untuk variabel leverage sebesar 0,601>0,10 dan nilai VIF sebesar $1,665<10$ sehingga variabel leverage dinyatakan tidak terjadi gejala multikolinieritas

\section{Uji autokorelasi}

Tabel 4. Uji autokorelasi

Berdasarkan hasil yang ditunjukkan pada tabel diatas diketahui bahwa nilai Durbin Watson hasil pengujian berada diantara $\quad \mathrm{du}<\mathrm{dw}<4$-du $(1.4625<1.6283<2.3717) \quad$ maka dapat disimpulkan bahwa tidak terjadi autokorelasi pada model regresi yang terbentuk. 


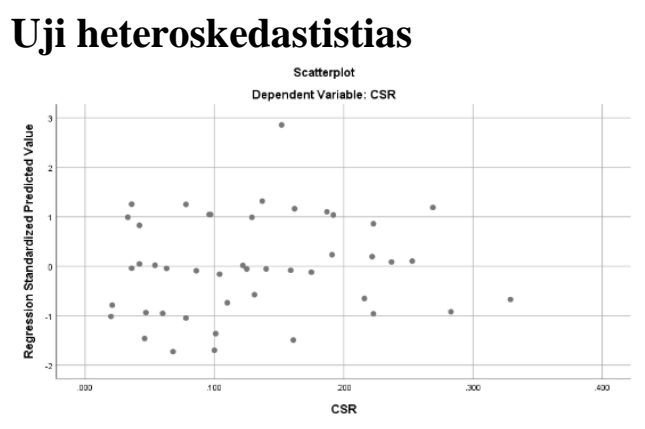

Gambar 2. Uji heteroskedasitas

Berdasarkan grafik scatterplot tersebut terlihat bahwa titik-titik menyebar secara acak serta tersebar baik diatas maupun dibawah angka 0 pada sumbu Y. Dengan demikian dapat disimpulkan bahwa tidak terjadi heteroskedastisitas pada model regresi.

\section{Uji koefisien Determinasi (R2)}

\begin{tabular}{lr}
\multicolumn{1}{c}{ Pengujian } & koefisien \\
determinasi adalah mengukur & menom \\
seberapa jauh kemampuan model \\
dalam menerangkan variabel \\
dependen.
\end{tabular}

Pada tabel diatas memperlihatkan $\mathrm{R}$ square dan adjusted $\mathrm{R}$ square masing-masing sebesar 0,161 dan 0,125 maka variabel corporate social responsibility dapat dijelaskan sebesar $12,5 \%$ dan sisanya oleh variabel likuiditas dan leverage.

\begin{tabular}{|c|c|c|c|c|c|}
\hline Model & $\begin{array}{l}\text { Sum of } \\
\text { Squares }\end{array}$ & $\mathrm{df}$ & $\begin{array}{l}\text { Mean } \\
\text { Square }\end{array}$ & $\mathrm{F}$ & Sig. \\
\hline Regression & .146 & 2 & .073 & 4.502 & $.016^{\mathrm{a}}$ \\
\hline Residual & .764 & 47 & .016 & & \\
\hline Total & .911 & 49 & & & \\
\hline
\end{tabular}

Hasil uji statistik F diperoleh Nilai $F$ hitung sebesar 4,502 dan Nilai Sig. adalah $0,016 \mathrm{~b}$ yang berarti $0,016 \mathrm{~b}<$ 0,05 maka disimpulkan bahwa seluruh variabel bebas, yaitu likuiditas dan leverage secara simultan berpengaruh terhadap variabel dependen yaitu pengungkapan corporate social responsibility.

\section{Uji parsial (Uji T)}

Tabel 6. Uji t

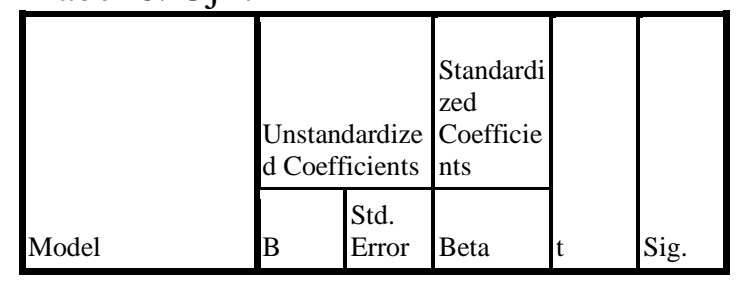

\begin{tabular}{|l|l|l|l|l|l|l|}
\hline Model & $\mathrm{R}$ & R Square & $\begin{array}{l}\text { Adjusted } \\
\text { Square }\end{array}$ & \multicolumn{2}{|l|}{$\begin{array}{l}\text { Std. Error of the } \\
\text { Estimate }\end{array}$} \\
\hline & $.401^{\mathrm{a}}$ & .161 & .125 & \multicolumn{3}{|l|}{} \\
\hline 1 (Constant) & .278 & .033 & & 8.510 & .000 \\
LIKUIDITAS & .037 & .016 & .396 & 2.299 & .026 \\
LEVERAGE & -.047 & .016 & -.508 & -2.947 & .005 \\
\hline
\end{tabular}

\section{Pengujian Hipotesis}

\section{Uji simultan (Uji F)}

Tabel 5. Uji F 
1. Hasil analisis data hipotesis pertama diketahui bahwa nilai $\mathrm{t}$ hitung benilai positif sebesar 2,299 dan dengan nilai probabilitas (Sig.) dari Likuiditas, yakni $0,026<0,05$ sehingga dapat disimpulkan bahwa variabel Likuiditas berpengaruh signifikan (secara statistika) terhadap Pengungkapan Corporate Social Responsibility.

2. Hasil analisis data hipotesis kedua diketahui bahwa nilai $\mathrm{t}$ hitung benilai negatif sebesar 2,947 dan dengan nilai probabilitas (Sig.) dari Leverage, yakni $0,005<0,05$ sehingga dapat disimpulkan bahwa variabel Leverage berpengaruh signifikan (secara statistika) terhadap Profitabilitas.

\section{Analisis Linier Regresi Berganda}

Dari data yang telah diolah yang dihasilkan pada tabel 6 dalam penelitian ini diperoleh analisis linier regresi berganda sebagai berikut:

$$
\begin{aligned}
& Y=0,278+0,037 X 1-0,047 X 2 \\
& +\varepsilon
\end{aligned}
$$

Berdasarkan persamaan regresi linear berganda di atas, diketahui:

1. Nilai konstanta sebesar 0,278 , berarti jika likuiditas, dan leverage nilainya adalah 0 , maka profitabilitas nilainya adalah 0,278 .

2. Nilai koefisien regresi dari likuiditas adalah 0,037 , artinya jika variabel ukuran perusahaan mengalami keniakan $1 \%$ maka profitabilitas mengalami kenaikan $\quad 3,7 \%$.Koefisien bernilai positif, artinya terjadi hubungan positif antara Likuiditas dengan Pengungkapan Corporate Social Responsibility

3. Nilai koefisien regresi dari Leverage adalah $-0,047$, artinya jika variabel Leverage mengalami keniakan $1 \%$ maka profitabilitas mengalami penurunan $4,7 \%$. Koefisien bernilai negatif artinya hubungan negatif antara Leverage dengan Pengungkapan Corporate Social Responsibility

\section{Pembahasan}

\section{Secara Parsial Hasil Pengaruh Likuiditas, dan Leverage terhadap Pengungkapan Corporate Social Responcibility}

$\begin{array}{cr}\text { Berdasarkan } & \text { hasil } \\ \text { perhitungan } & \text { statistic }\end{array}$ pasrsial dari Likuiditas menunjukkan nilai koefisien bernilai positif sebesar 2,299 dengan nilai probabilitas (Sig.) yakni $0,026<0,05$ hal ini berarti variabel Likuiditas berpengaruh positif dan signifikan terhadap pengungkapan corporate social responsibility. Hasil penelitian menyatakan bahwa $\mathrm{H} 1$ diterima.

H1 = Likuiditas berpengaruh signifikan terhadap 


\section{pengungkapan corporate social responsibility}

Hasil Perhitungan statistik secara parsial dari Leverage menunjukan nilai koefesien benilai negatif sebesar 2,947 dan dengan nilai probabilitas (Sig.) dari Leverage, yakni $0,047<0,05$ hal ini berarti variabel Leverage berpengaruh negatif signifikan terhadap Pengungkapan Corporate Social Responsibility. Hasil penelitian menyatakan bahwa $\mathrm{H} 2$ diterima.

H2 =Leverage berpengaruh terhadap pengungkapan social responsibility

\begin{tabular}{lrr} 
Secara & \multicolumn{1}{c}{ Simultan } & Hasil \\
Pengaruh & Likuiditas & dan \\
Leverage & Terhadap \\
Pengungkapan & Corporate \\
Social Responsibility &
\end{tabular}

Berdasarkan hasil analisis perhitungan statistik secara simultan menjukna nilai f hitung sebesar 4,502 dan nilai Signifikan adalah $0,016 \mathrm{~b}$ yang berarti $0,016 \mathrm{~b}$ $<0,05$ maka disimpulkan bahwa seluruh variabel bebas, yakni likuiditas dan leverage secara simultan berpengaruh signifikan terhadap pengungkapan corporate social reponsibility.

H3 =Likuiditas dan $\begin{array}{r}\text { Leverage } \\ \text { terhadap } \\ \text { berpengaruh } \\ \text { pengungkapan } \\ \text { responsibility }\end{array}$
social

\section{KESIMPULAN DAN SARAN}

\section{Kesimpulan}

1. Berdasarkan hasil uji penelitian menunjukan bahwa likuiditas pada perusahaan manufaktur secara parsial berpengaruh positif dan signifikan terhadap variabel pengungkapan corporate social responsibility perusahaan, Hal ini berarti $\mathrm{HO}$ ditolak dan $\mathrm{H} 1$ diterima, hal ini terjadi karena Likuiditas yang tinggi menunjukkan kekuatan perusahaan dari segi kemampuan untuk memenuhi hutang lancar dari harta lancar yang dimiliki sehingga hal ini dapat meningkatkan pengungkapan corporate social responsibility perusahaan tersebut. Sehingga tingkat likuiditas dapat mempengaruhi pengungkapan corporate social responsibility suatu perusahaan. Karena Hipotesis (H1) diterima, maka Likuiditas dapat digunakan untuk menentukan tingkat pengungkapan corporate social responsibility pada perusahaan Manufaktur yang terdaftar di Bursa Efek Indonesia (BEI) periode 20152019.

2. Berdasarkan hasil uji penelitian menunjukan bahwa leverage perusahaan manufaktur secara parsial berpengaruh negatif signifikan terhadap profitabilitas perusahaan. Hal ini berarti $\mathrm{H} 0$ 
ditolak dan $\mathrm{H} 2$ diterima, hal ini terjadi karena semakin besar rasio leverage menunjukan bahwa semakin besar biaya yang harus di tanggung oleh perusahaan untuk memenuhi kewajiban yang dimiliki perusahaan tersebut sehingga dapat menurunkan pengungkapan corporate social responsibility yang dimiliki oleh perusahaan. Namun apabila nilai rasio leverage rendah, maka akan semakin tinggi jumlah pendanaan yang disediakan oleh pemilik perusahaan. Sehingga tinggi rendahnya leverage dapat mempengaruhi pengungkapan corporate social responsibility suatu perusahaan. Karena Hipotesis (H2) diterima, maka leverage dapat digunakan untuk menentukan tingkat pengungkapan corporate social responsibility pada perusahaan Manufaktur yang terdaftar di Bursa Efek Indonesia (BEI) periode 20152019.

3. Hasil analisis Uji F menunjukan bahwa likuiditas dan leverage perusahaan manufaktur secara simultan memiliki pengaruh secara signifikan terhadap pengungkapan corporate social responsibility perusahaan. dengan hasil analisis diperoleh Nilai $F$ hitung sebesar 4,502 dan nilai Signifikan adalah 0,016 b yang berarti $0,016 \mathrm{~b}<0,05$ maka disimpulkan bahwa seluruh variabel bebas, yakni likuiditas dan leverage secara simultan berpengaruh signifikan terhadap pengungkapan corporate social reponsibility.

4. Hasil Uji Adjusted R Square pada penelitian ini sebesar 0,161 atau sama dengan $16,1 \%$. Hal ini berarti bahwa variabel Likuiditas dan Leverage secara simultan berpengaruh terhadap variabel Pengungkapan Corporate Social Responsibility sebesar $16,1 \%$ sedangkan sisanya $83,9 \%$ dipengaruhi oleh variabel lain yang tidak ditelit

\section{Saran}

1. Penelitian ini terbatas hanya pada perusahaan manufaktur yang terdaftar di bursa efek Indonesia. Bagi peneliti selanjutnya, objek penelitian ini dapat di perluas tidak hanya pada perusahan manufaktur saja. Dan sebaiknya di lakukan penelitian lebih lanjut terhadap beberapa variabel lain yang dapat mempengaruhi pengungkapan corporate social responsibility, agar dapat meningkatkan akurasi hasil penelitian menjadi lebih baik, dan mengetahui dengan jelas variabel lain yang mempengaruhi corporate social responsibility. 
2. Penelitian ini memberikan bukti adanya pengaruh dari variabel Likuiditas terhadap pengungkapan corporate social responsibility khususnya pada perusahaan manufaktur yang terdaftar di Bursa Efek Indonesia periode 2015-2019. Untuk itu Bagi perusahaan penelitian ini diharapkan perusahaan mengungunakan program CSR karna program CSR mempu meningkatkan tanggung jawab sosial pada perusahaan tersebut dan mampu meningkatkan pengelolaan CSR dalam mengambil keputusan, sehingga perusahaan sebaiknya tetap melaksanakan program CSR secara kontinyu. Karena dengan melaksanakan program tersebut perusahaan akan memperoleh pengakuan yang lebih oleh masyarakat dan kreditur.

3. Bagi pembaca diharapkan untuk melakukan penelitian dan pengembangan lebih lanjut serta memperluas ruang lingkup penelitian, dan menambah objek dari berbagai sektor agar dapat memberikan referensi kepada investor, calon investor, dan pengguna lain untuk pengambilan keputusan investasi yang lebih baik.

\section{DAFTAR PUSTAKA}

Arif, F. A., \& Wawo, A. (2016). Pengaruh Ukuran Perusahaan, Leverage, dan Likuiditas Terhadap Pengungkapan Corporate Social Responsibility dengan Profitabilitas sebagai Variabel Moderasi. Assets, 6(2), 177-195.

Laksmitaningrum, C. F., \& Purwanto, A. (2013). Analisis Pengaruh Karakteristik Perusahaan, Ukuran Dewan Komisaris, Dan Struktur Kepemilikan Terhadap Pengungkapan CSR. In Diponegoro Journal of Accounting (Vol. 2, Issue 3).

Astuti, T. (2013). Pengaruh Profitabilitas, Likuiditas dan Leverage terhadap Pengungkapan Islamic Social Reporting.(Studi Empiris pada Perusahaan yang Terdaftar di JII tahun .... ... Islamic-Social-Reporting-StudiEmpiris-Pada https://www.iqtishadconsulting.co $\mathrm{m} /$ assets/media/file/file-pengaruhprofitabilitas-likuiditas-danleverage-terhadap-pengungkapanislamic-social-reporting-studiempiris-pada-perusahaan-yangterdaftar-di-jii-tahun-20102012.pdf

Bagus, I., Indra, G., Purba, W., \& Yadnya, P. (2015). Pengaruh Ukuran Perusahaan Dan Leverage Corporate Social Responsibility Fakultas Ekonomi dan Bisnis Universitas Udayana ( Unud ), Bali, Indonesia ( 2011 ) 
mendapatkan hasil bahwa leverage berpengaruh positif terhadap. 4(8), 2428-2443.

Sukenti, S., Hidayati, N., \& Mawardi, M. C. (2017). Pengaruh Profitabilitas, Likuiditas, dan Growth Terhadap Pengungkapan Tanggung Jawab Sosial Perusahaan (Studi Pada Perusahaan Manufaktur Yang Terdaftar di BEI Tahun 20132015). Universitas Islam Malang, 19 , 15-33. https://doi.org/10.1186/17558794-3-33

Tanggung, K. P., Indonesia, B. E., Responsibility, C. S., Rokhman, T. N., Ekonomi, F., Universitas, B., \& Malang, W. (2013). Pengaruh Size, Profitabilitas, Dan Likuiditas Terhadap Corporate Social Responsibility (Csr) (Studi Empiris Pada Perusahaan LQ-45 yang Terdaftar Di BEI) M.Taufiq Noor Rokhman 9 ). 25(2), 195-203.

Lucyanda, J. (2012). The Influence of Company Characteristics Toward Corporate Social Responsibility Disclosure. Viii, 601-619.

Hussainey, K. (2011). FACTORS AFFECTING CORPORATE SOCIAL RESPONSIBILITY DISCLOSURE IN EGYPT. July.

Irham, A. R., Yuliana, S., \& Widiyanti, M. (2018). The effect firm characteristic on corporate social responsibility disclosure in the firms listed in Indonesia Sharia Stock Index. 6(3), 303318.
No, V. (2018). Journal of Finance and Islamic Banking. 1(2), 133149.

Giannarakis, G. (2014). Corporate governance and financial characteristic effects on the extent of corporate social responsibility disclosure. https://doi.org/10.1108/SRJ-022013-0008

Achmad Zaenuddin. 2007. Faktor-Faktor Yang Berpengaruh Terhadap Praktek Pengungkapan Sosial Dan Lingkungan Pada Perusahaan Manufaktur Go Publik. Tesis. Universitas Diponegoro.

Fahrizqi, Anggara. 2010. FaktorFaktor yang Mempengaruhi Pengungkapan Corporate Social Responsibility (CSR) dalam Laporan Tahunan Perusahaan (Studi Empiris pada Perusahaan Manufaktur yang Terdaftar dalam Bursa Efek Indonesia). Skripsi Sarjana Jurusan Akuntansi pada Fakultas Ekonomi Universitas Diponegoro. Semarang.

rzully, N., dan P. Denies. 2012. Analisis Faktor-Faktor Yang Mempengaruhi Pengungkapan Corporate Social Responsibility pada Perusahaan Manufaktur Yang Terdaftar di Bursa Efek. Jurnal Nominal 1(1):22-34.

tariani.2014. Pengaruh Karakteristik Perusahaan dan Tanggung Jawab Lingkungan pada Pengungkapan Tanggung Jawab Sosial Perusahaan.EJurnal Akuntansi Universitas Udayana.h: 402-418. 
Prihastuti, Theresia. 2008. Analisis Pengaruh Ukuran Perusahaan, Likuiditas, Leverage, dan Profitabilitas Terhadap Voluntary Disclosure (Study Empiris pada Perusahaan Manufaktur yang Tercatat di Bursa Efek Jakarta Tahun 20032006, Rangkuman Skripsi Sekolah Tinggi Ilmu Ekonomi Perbanas. Surabaya. utri, Rafika Anggraini dan Yulius Jogi Christiawan. 2014. Pengaruh Profatibilitas, Likuiditas, dan Leverage terhadap Pengungkapan Corporate Social Responsibility (Studi pada PerusahaanPerusahaan yang Mendapat Penghargaan ISRA dan Listed (Go-Public) di Bursa Efek Indonesia (Bei) 2010-2012). Jurnal Business Accounting Review.Vol. 2, No. 1.

Ramadhaningsih Amalia dan I Made Karya Utama. 2013. Pengaruh Indikator Good Corporate Governance dan Profitabilitas Pada Pengungkapan Corporate Social Responsibility. E-Journal Akuntansi Universitas Udayana. Bali.

Rosyadi, Risky Latif. 2015. Pengaruh Ukuran Perusahaan, Profitabilitas, Likuiditas, dan Media Exposure Terhadap Pengungkapan Corporate Social Responsibility. Skripsi. Fakultas Ekonomi. Universitas Negeri Semarang. Sari, R.A. 2012. Pengaruh Karakteristik Perusahaan terahadap Corporate Social Responsibility Disclousre pada Perusahaan Manufaktur
Yang Terdaftar di Bursa Efek Indonesia. Jurnal Nominal 1(1): 124-140.

Situsresmi: $\quad$ www.idx.co.id diakses Januari 2020.

Suhaenah. 2012. Analisis Pengaruh Ukuran Perusahaan, Profitabilitas Dan Leverage Terhadap Pengungkapan Tanggung Jawab Sosial Perusahaan (Corporate Social Responsibility Disclosure). Skripsi. Universitas Gunadarma. Rheza, Dwi Respati dan Paulus Basuki Hadiprajitno, 2015. Analisis Pengaruh Profitabilitas, Leverage, Ukuran Perusahaan, Tipe Industri, Dan Pengungkapan Media Terhadap Pengungkapan Corporate Social Responsibility. Jurnal Universitas Diponegoro

Dewi, P. A. C., \& Sedana, I. B. P. (2019). Pengaruh Profitabilitas, Ukuran Perusahaan, Dan Leverage Terhadap Pengungkapan Corporate Social Responsibility. E-Jurnal Manajemen Universitas Udayana, $8(11)$, 6618. https://doi.org/10.24843/ejmunud. 2019.v08.i11.p12

Natalia, P. (2015). Pengaruh Profitabilitas, Pertumbuhan Penjualan, Struktur Aktiva, Dan Risiko Bisnis Terhadap Struktur Modal Pada Emiten Kompas 100 (Non Perbankan). Jurnal Manajemen Maranatha, 14(2), 114942.

Fauziah, I. (2019). Pengaruh Profitabilitas, Likuiditas, Leverage , Ukuran Perusahaan Dan Ukuran Dewan Komisaris 
Terhadap. Jurnal Ilmu Dan Riset Akuntansi, 8, 3.

Arif, F. A., \& Wawo, A. (2016). Pengaruh Ukuran Perusahaan, Leverage, dan Likuiditas Terhadap Pengungkapan Corporate Social Responsibility dengan Profitabilitas sebagai Variabel Moderasi. Assets, 6(2), 177-195.

Ayu, I., \& Laksmidewi, P. (2019). Pengaruh Leverage, Likuiditas, Profitabilitas Dan Ukuran Perusahaan Terhadap Pengungkapan Corporate Social Responsibility. E-Jurnal Manajemen Universitas Udayana, 8(9), 5372-5400.

Astuti, T. (2013). Pengaruh Profitabilitas, Likuiditas dan Leverage terhadap Pengungkapan Islamic Social Reporting.(Studi Empiris pada Perusahaan yang Terdaftar di JII)

Bagus, I., Indra, G., Purba, W., \& Yadnya, P. (2015). PENGARUH
UKURAN PERUSAHAAN DAN LEVERAGE CORPORATE SOCIAL RESPONSIBILITY Fakultas Ekonomi dan Bisnis Universitas Udayana ( Unud ), Bali , Indonesia ( 2011 ) mendapatkan hasil bahwa leverage berpengaruh positif terhadap, 4(8), 2428-2443.

Putri, R. K. (2017). Pengaruh Ukuran Perusahaan, Profitabilitas, Leverage, dan Basis Kepemilikan Terhadap Corporate Social Responsibility Pada Perusahaan Pertambangan Yang Terdaftar di Bursa Efek Indonesia (BEI) periode Tahun 2012-2014. JOM Fekon, 4(1), 558-571.

Hamzah, A. dan S. R. (2019). Faktor Yang Mempengaruhi Pengungkapan Tanggung Jawab Sosial Perusahaan Pada Sub Sektor Pertambangan Batubara Periode 2013-2018. Journal of Islamic Finance and Accounting, 2(2), 99-117. 